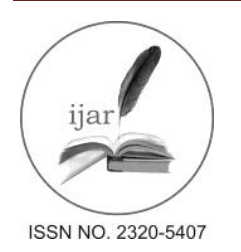

Journal homepage: http://www.journalijar.com

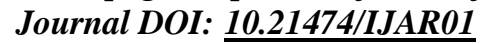

INTERNATIONAL JOURNAL

OF ADVANCED RESEARCH

RESEARCH ARTICLE

\title{
COMPARATIVE STUDY ON SELF-ESTEEM AT CHILDREN WITH SCOLIOSIS AND THOSE NOT DIAGNOSED WITH THIS DISABILITY.
}

*Sava Nicu-Ionel and Antemir Cristina-Laura.

Department of Social Sciences, Andrei Saguna University Constanta, Romania.

\section{Manuscript Info}

Manuscript History:

Received: 12 May 2016

Final Accepted: 12 June 2016

Published Online: July 2016

Key words:

disability,self-esteem,

multidisciplinary.

*Corresponding Author

Sava Nicu-Ionel.

\begin{abstract}
The overall objective of the research is to raise the awareness of specialists working in multidisciplinary teams in order to improve school performances by increasing self-esteem in children with motor disabilities. Achieving this goal will be possible by resorting to a set of multidisciplinary strategies for self-esteem boost. Self-esteem is closely linked to self-confidence and it is said that if a person has confidence, it is likely that it may act as a thinking being and be able to achieve their goals. This belief about themselves can have a major influence on the work carried out by individuals or by children, because it works and is a motivational factor, influencing their behavior.
\end{abstract}

Copy Right, IJAR, 2013,. All rights reserved.

\section{Introduction:-}

The term of scoliosis is due to Galen (130-210 A.D.), he defined it as a deviation of the spine in coronal plane. Analysis column deviations in coronal plane - namely scoliosis - is facilitated because normally there is no physiological curvature.

Differentiation must be made between hard functional scoliosis (scoliosis attitudes) which are deviations coronal plane spinal where the vertebrae and discs anatomy is normal. Only the coronal plane alignment is disturbed and structural scoliosis, which are scoliosis whose vertebrae have structural changes (irritation, cuneiform, etc.), whose curves are irreducible clinical and radiographic when lying down and generally, have an evolutionary trend.

Etiology: Despite various research done, little is known about the etiology of idiopathic scoliosis. Various factors such as an increase in asymmetric changes in neuromuscular, connective tissue abnormalities or configuration changes sagittal spine were indicted in onset of scoliosis.

Heredity is now accepted and regarded as idiopathic scoliosis is the result of a multifactorial disorder. Hereditary factor was invoked due to frequent occurrence of scoliosis in several members of the same family. The mode of transmission was considered autosomal dominant, (Faber) or sex linked dominant (Cowell Hall, and Mac Ewen). Studies by Wynne-Davies noted scoliosis 7\% to grade 1 relatives, $3.7 \%$ to rade 2 relatives and $1.6 \%$ to grade 3 relatives, the highest incidence being observed in girls of grade $1(12 \%)$. The transmission is considered to be multifactorial. To the same conclusion, multifactorial heredity, have reached Fiho and Thompson (1971).

Environmental factors are considered to be also important.

The age of mothers of children with idiopathic scoliosis is higher then of general population, birth can be frequently pelvic, records show that these mothers have an increased incidence of hernias.

Growth is a complex phenomenon influenced by hereditary factors, hormonal and environmental. Very little is known about the interaction of these regulatory factors. It is known that there is a link between growth and idiopathic scoliosis; structural scoliosis develops with growth; spinal deformity gets worse in periods of rapid growth. 
Several authors have analyzed the correlation between skeletal age and chronological age in girls with idiopathic scoliosis. Nordwall and Willner observed the skeletal maturation observed before 13 years. This would indicate an accelerated growth in prepubertal difference between skeletal maturation and a growth model to girls with idiopathic scoliosis deviated from the normal. On the contrary, Buric and Monicilovic found delayed skeletal maturation cases with scoliosis. The hormone system, which plays an important role in regulating the growth, was made responsible in the idiopathic scoliosis. Increased secretion of pituitary growth hormone has been reported between 7 to 12 years, children with idiopathic scoliosis. Other hormones that influence growth in September thyroxine, prolactin, cortisol) were studied to find differences between people with scoliosis and control population without finding significant data.

Clinical trials in patients with idiopathic scoliosis showed the presence of disorders of the balance system. Yamada et al., noted that in 150 cases, $79 \%$ failed in maintainig the balance system. In the unsocliotic control population, these disorders were detected in only 5\% of the cases. Postural oscillations were greater in small scoliosis curvatures cases $(<20 \%)$, than in the severe ones.

Weight tends to close the ends of the column, so to accentuate the curvature. This way, it appears that a shift is achieved, on the one hand, the direction of the vertical center of gravity, and secondly the direction of the vertical passing through the center of each section of the spine (each vertebrae).

If we do not know the exact mechanism of idiopathic scoliosis today, it is known precisely that over a certain degree of curvature, progressive worsening of the scoliosis is inevitable due to growth and biomechanical factors. The factor that can be influenced by current therapy is biomechanical. As much as possible, avoid crossing the threshold that makes the evolution of scoliosis to become invalidant. If this threshold is passed, one should try to neutralize the forces that worsens the curvature, the degree of curvature should be rectified and column should be the fusioned in the deformed area.

Treatment principles: act of great responsibility, fair treatment of idiopathic scoliosis or kyphosis can only be done in a multidisciplinary team. Orthopedic doctor, the functional exploration, radiologist, physical therapist, prosthetist, but also psychologist and social worker must work în pursuing this type of treatment of motor deficits. Therapeutic indication must be nuanced, individualized to each case separately, to take into account not only the medical peculiarities of the case given, but also the family and pursuing opportunities to family therapy.

Much of idiopathic scoliosis have an evolutionary potential, especially if they exceeded a certain threshold of severity. This development, governed by laws and independent biomechanical initial cause is maintained throughout the period of growth and not infrequently, în serious cases, lifelong. Steady worsening of vertebral deviation can result in, especially if the onset scoliosis was early, respiratory and finally heart disorders. The diagnosis of idiopathic scoliosis will have to eliminate the known causes of occurrence of spinal deviations and will have to clarify its seriousness and its evolving risk.

Taking into account all these elements, therapeutic indication must be followed and a therapeutic program must be achieved and everything must be strictly controlled by the family and medical doctor. In addition, therapeutic indication must be constantly adjusted function of the results and the remaining period of evolution.

\section{Material and Methods:-}

\section{Objective:-}

Assessing the level of self-esteem in children with motor deficit (scoliosis) and spine compared to students without motor deficit.

\section{Participants:-}

The research takes into account a batch of 60 students in primary grades, enrolled in mainstream education, aged 7 years, of which:

* 30 subjects with motor deficit like scoliosis;

- 30 subjects considered normal, no somatic and / or functional deficit.

\section{Instrument:-}

* Cvasiexperimental explorative quantitative and qualitative method. 
* Rosenberg test for assessing self-esteem.

\section{Procedure:-}

* Applying the Rosenberg test for self-esteem to the children

\section{Result and Discussion:-}

After applying the tests, creating the database (SPSS), the data processing revealed the following:

$>$ The distribution of self-esteem variable does not meet the normality conditions;

$>$ The right test is a nonparametric test (Mann Whitney $\mathrm{U}$ ) compared to averages of ranks obtained by both types of self-esteem variable subjects;

$>$ The comparison result is that research supports the hypothesis $\mathrm{Z}=-5.72, \mathrm{p}<.001$;

$>$ The value of $Z$ and materiality indicate that among subjects with scoliosis and those without this condition there is a significant difference in the level of self-esteem;

$>$ Subjects with scoliosis record levels of significantly lower self-esteem.

$>$ Null hypothesis was rejected.

Integration of children with disabilities is a continuing concern of society which unfortunately is not successful. Work must be done in multidisciplinary teams to have a unified vision of all the aspects involved or associated with a particular disability. The research took into account motor disabilities (scoliosis), more specifically, its correlates. Therefore, self-esteem was assessed in a group of 60 subjects, children in mainstream schools, 30 were diagnosed with scoliosis and 30 having such a disability. The research method was exploratory one quasi-experimental using an established instrument for assessing self-esteem. After verifying the research hypothesis was confirmed. Recalling that self-esteem is closely related to self-confidence, which turns into a real motivator, I believe that an approach for psycho-educational evaluation and stimulation of self-esteem is better, thus facilitating improving school performance and increased chances of integrating children with disabilities.

\section{References:}

1. Albu, C., Albu, M. (2012). Kinetoterapie - metodologia poziţionării şi mobilizării pacientului. (Kinetotherapy - methodology of positioning and mobilizing the patient). Iaşi: Editura Polirom;

2. Barbu, G. P. (2014). Copilul şi motricitatea - program de educare neuromotorie. (Children and motricity neuro-motor education program). Piteşti: Editura Nomina;

3. Boza, M. (2010). Atitudinile sociale şi schimbarea lor (Social attitudes and their change), Iaşi: EdituraPolirom;

4. Gherguț, A. (2001). Psihopedagogia persoanelor cu cerinţe speciale - Strategii de educaţie integrată. (Psihopedagogy of special needs persons - Strategies for integrated education). Iaşi: Editura Polirom;

5. Jianu, M., Zamfir, T. (1995). Ortopedie şi traumatologie pediatrică. (Pediatric orthopedy and traumatology). Bucureşti: EdituraTradiţie. 